\title{
External Resources and Economic Growth: An Empirical Analysis of South Asian Countries
}

\author{
Imtiaz Arif * \\ Lubna Khan \\ Syed Ali Raza*
}

Abstract: This study aims to investigate the role of three important external resources on the economic growth of leading South Asian countries. A sample of four countries is studied from 1983 to 2014. Empirical analyses are carried out in two phases. First, we have checked the combined effect using CD test, CIPS, Pedroni, and Westerlund panel cointegration, pooled mean group (PMG) framework and Heterogeneous non-causality test. In the second phase, we compared the regional and country-wise estimations using ARDL bound testing, stability test, and Granger causality. Results suggest that remittances play a vital role in the economic growth of selected South Asian countries, whereas, imports and foreign direct investment found to be insignificant. Also, while evaluating the same model for the individual countries using the ARDL estimations also reveal that remittances significantly contribute to the economies of Pakistan and Sri Lanka and imports found to be negatively related with economic growth in the same economies. However, imports showed a strong relationship with the economic growth of Bangladesh. Thus, this paper has drawn some insights for the policymakers.

Keywords: external resources; GDP; South Asian countries; cross-sectional dependence; heterogeneity; PMG framework

JEL Classification: $\mathrm{O}, 05,057$

\section{Introduction}

Economic growth is inevitable for attaining the overall economic progress of the country. However, it is a major challenge for the countries to achieve desired economic growth for a long time period. Denault (2011) identified that foreign capital

\footnotetext{
${ }^{*}$ Imtiaz Arif, Lubna Khan and Syed Ali Raza are at Department of Business Administration, Iqra University, Karachi, Pakistan.
} 
plays an imperative role in the economic development and further argued that foreign capital is an important determinant of economic growth regardless of its origin. This research focuses on three important foreign capital sources that are foreign direct investment, remittances, and imports. Foreign direct investment is considered one of the most effective external resources that directly affect the economy, particularly, in developing countries (Villaverde \& Maza, 2014). Foreign investments not only increase the capital formation but also bring technology, expertise, infrastructure and other benefits. After FDI, remittances are the core external resource that boosts the economy. It spurs the purchasing power of the recipient household and raises the domestic investment. Import is another external factor that directly or indirectly benefits the economy. The free flow of trade raises the economic growth as well as contribute to the reduction of poverty (Manni, Siddiqui \& Afzal, 2012).

Economic theory posits that free flow of foreign capital across borders is useful for the economic growth of all the countries. However, sometimes capital liberalization policies distort the economic activities. In the aftermath of the global financial crisis in developed nations, the graph of foreign capital inflow has moved to developing nations. According to the World Bank report (2016), South Asia is considered the most resilient regions in the volatile international markets. It has become the second-fastest growing region in the world with the recorded economic growth of $7.1 \%$ in 2016, $6.9 \%$ in 2017 and expected to grow 7.1\% in 2018. India, the largest economy of South Asia, the economic growth was recorded 7.2\% in 2017, 6.8\% in 2016 and $7.5 \%$ in 2015, due to the foreign and domestic investments. The Foreign direct inflows in India are static, measured as \$44 billion and remittances have dropped by $8.9 \%$ in 2016 , recorded $\$ 62.1$ billion. Bangladesh is considered the leader of the garment industry in South Asia with the projected GDP growth of 6.9\% in 2017-2018. Remittances, exports and foreign investment, mostly in the textile sector are the key drivers that run the economic engine of Bangladesh. Foreign direct inflows are raised by $4.25 \%$, amounted to $\$ 2.3$ billion in 2016, whereas, remittances flow is recorded as USD 2.1 billion in 2016. Pakistan, one of the growing economy of South Asia, economic growth is recorded as $4.8 \%$ in 2017 , due to the recent investments, the foreign inflows have raised by 56\% in 2016 and remittances are expected to be $5.5 \%$ in the coming years. Srilanka is another developing state of South Asia; the GDP growth is recorded as 5.3\% in 2016, the foreign direct investment increased and recorded as USD 636 million in 2016, whereas, remittances are expected to increase $3.7 \%$ in the next year. 
Figure 1: External resources and economic growth in the South Asian countries (1983-2014)
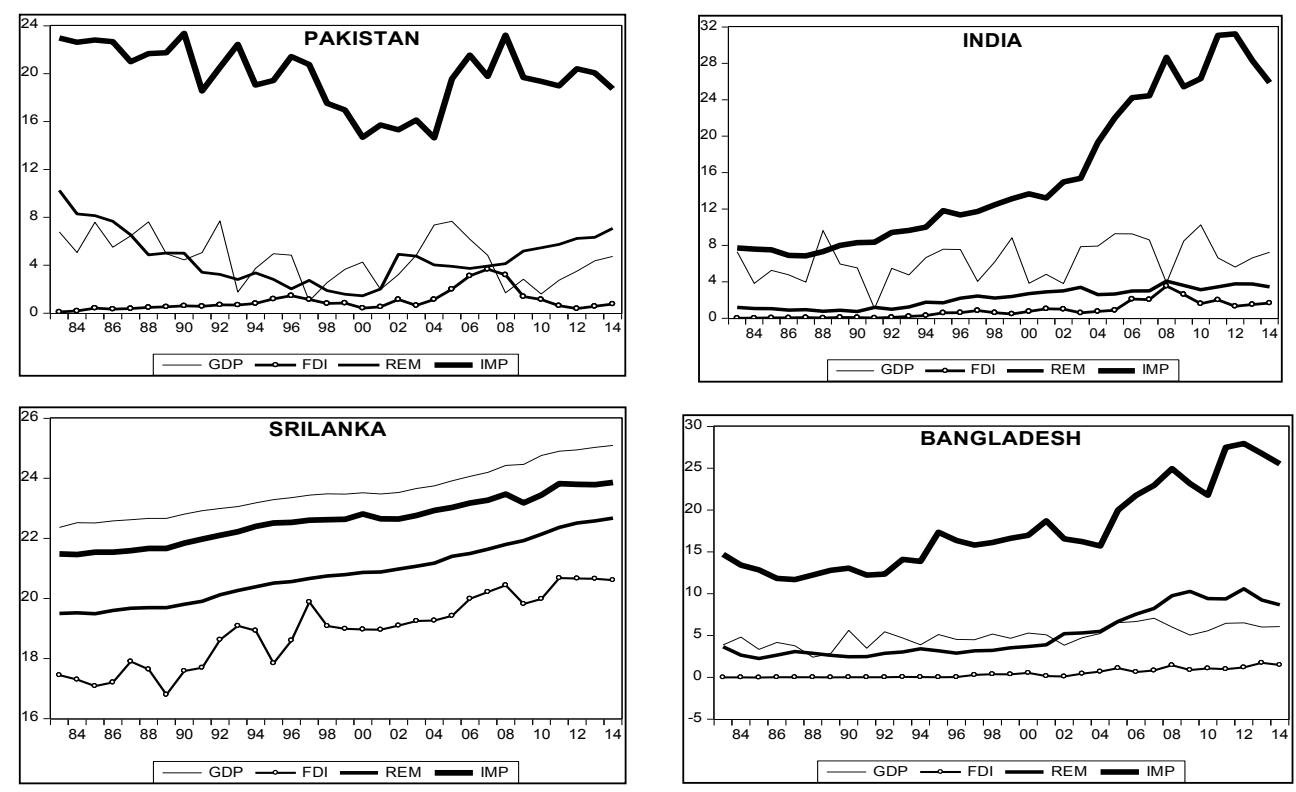

In this study, we aim to investigate the effects of external resources on the economic growth of South Asia. South Asian Economic Focus reported that South Asia is the fastest growing region around the world and even found the most resilient region in the turbulent situations. At the time of global financial distress, the foreign capital moved from developed countries to developing nations. In the empirical growth literature, there are five external factors that directly or indirectly affect the economic growth, which is, FDI, remittances, imports, foreign aid and external debt. We have taken three important external resources such as remittances, imports, and FDI, which is used to raise capital formation in the country. Foreign direct investment raises capital by bringing foreign advanced technology, expertise, knowledge, and infrastructure. Remittances are used to boost the consumption power of the families which resulted in savings and investments. Importing raw material and domestically converting into a finished goods increase the productivity and output of the country. However, foreign aid and foreign debt also bring external finance and foreign earnings in the country, but it sees detrimental for the economy in the long run. One shortcoming of foreign aid is the political and economic exploitation. Sometimes donor countries intervene or control the political and economic decisions of the recipient countries. Also, foreign debt hinders the economy to grow because governments generate money to repay the amount rather than to use it for the development purpose. 
Due to the financial crisis, large and volatile capital flow to the developing nations motivated us to investigate the combined effect of external factors that generate capital formation in the country. Earlier a similar study with different methodology was carried out for emerging and growth leading economies (EAGLE) by Arif, Khan, Raza \& Maqbool (2017). Findings of this research motivated authors to probe further the impact of external resources in the development of South Asian leading economies in detail using both panel analysis for region and time series analysis for individual countries. Apart of this study, other studies have only focused on the individual impact of capital inflows on the economic growth. Therefore, this research contributes to the empirical literature in two ways; first, the study focuses on the combined effect of three external resources that contribute to the economic growth of leading economies of South Asia, namely Pakistan, India, Bangladesh, and Sri Lanka. Second, we test the hypothesis by using several advanced econometric techniques Such as CD test, CIPS, Westerlund and PMG estimation. Further, we apply different techniques that can address the issue of cross-section dependence and heterogeneity among sample countries. For that reason, we employ Pesaran (2004) cross-sectional dependence (CD) test to identify a cross-sectional dependency between studying variables. Whereas, the second generation Pesaran (2007) panel unit root, i.e., CIPS test is used to assess the stationarity of the data series. The two robust panel cointegration techniques are implemented, i.e., Westerlund (2007) and Pedroni $(1999,2004)$ to determine the long run association among variables. For estimating a model, we adopt Mean Group (MG) and Pooled Mean Group (PMG) estimations. In the last step, we used Dumitrescu and Hurlin (2012) heterogeneous non-causality approach to check the causal relationship between studying variables. The study will also be beneficial for policy makers, business sectors and individuals who monitor the flow of FDI, remittances, and imports in the country.

Following the introductory section, the remainder of this paper is structured as follows. Section II briefly discusses the empirical literature. Section III describes the model, data, and methodology. Section IV reports the empirical findings and the last section $\mathrm{V}$ concludes the entire study with some policy implications.

\section{Literature Review}

Foreign direct investment is one of the key determinants of external resources that contribute to the economy. Neoclassical theory depicts that the inflow of foreign investment is important because it fills the gap between savings and investments (Solow, 1956). FDI acts as an economic engine that raises the growth by bringing investments, knowledge, expertise, technologies, employment, and many others. Also, new growth theory postulates that foreign direct investments are more important than local investments because it brings advanced technologies and infrastructure 
that lead to economic growth. The endogenous growth theory stated the direct and indirect benefits of FDI in the recipient country. The level of investment and improvement of technology directly affects the economy, whereas, human development and governance and layout indirectly benefit the economy.

Numerous studies have been conducted that highlight the importance of foreign direct investment on the economic growth. FDI inflow is pivotal for the economy because it transfers advance technologies and helps domestic businesses (Barro \& Lee, 1993). In the other study, the authors find out the positive and significant effect of foreign direct inflows on the economic development (Jawaid \& Saleem, 2017; Jawaid \& Raza, 2016; Almfrsji \& Almsafir, 2014). A case study in Malaysia conducted by Tang and Tan (2014) revealed a high correlation between foreign direct investment and economic growth. However, Iamsiraroj and Ulubaşoğlu (2015) posit that there is a strong relationship between direct investment and economic growth, but it varies regionally. Several researchers have found a positive and significant relationship between foreign investments and economic growth in both the long run and short run period. Balamurali and Bogahawatte (2011) checked the causal relationship between FDI and economic growth and found a bidirectional relationship between both the variables. Similarly, a study found a causal relationship between FDI and economic growth in different sectors. For instance, in the services and primary sector, unidirectional causality found between variables, however, in the manufacturing sector, the economic growth attracts the foreign inflows.

Conversely, some researchers have found the negative influence of foreign investments on the gross domestic product. Hermes and Lensink (2003) cited that financial system of an economy drives the positive and negative impact of foreign investment on the gross domestic product. Bashir et al. (2014) ratified the importance of FDI but also mentioned that bad governance, weak infrastructure, unfriendly business environment and weak government policies inversely influence the economy of developing nations. In some past studies, the authors found a negative association between foreign direct investment and gross domestic investment ( $\mathrm{Li}$ and Liu, 2005 \& Borensztein et al.; 1998).

The other external resource that plays a crucial role in the economic development is remittances. It has a substantial role in the recipient economy. Remittances can flow into the country through a legal channel or illegal channel. Remittances flow through legal channels, developed the financial system, and contribute to the economy in their development. However, remittances through illegal channels can have a negative or no impact on the economic development. Several studies noted the significant positive influence of remittance on economic growth (Kumar \& Stauvermann, 2014; Jawaid \& Raza, 2012; Hussain \& Anjum, 2014), few studies also noted the positive but weak relationship between the two (Rao and Hassan, 2011 \& Catrinescu et al., 2009). Moreover, Das and Chowdhary (2011) claimed that free flow of remittances raises the purchasing power of the recipient household. It also strengthens and 
reinforces the financial institutions (Demirgüç-Kunt and Peria, 2011 \& Giuliano and Arranz, 2009). It is also recorded that remittances open up the investment channels particularly in the developing nations (Nwaogu and Ryan, 2015; Driffield and Jones, 2013; Khathlan, 2012; Lueth, 2006).

In contrast with the above studies, some developing nations have noticed negative effects of remittances on economic growth. It is indeed evidence found that remittances contribute to the poverty reduction but sometimes harm the economy. Imai et al. (2014) found the mixed effect of remittances on the economy; they stated that flow of remittances improve the economic performances as well as become a source of shocks. Brain drain is one of the biggest problem facing by several developing countries (Niimi, Ozden \& Schiff, 2010). In some developing nations, it is noted that remittances flow obstruct the economy to grow. Because there is no long-run effect of remittances on the economic development. A study of Barajas et al. (2009) found a negative association of remittances on economic growth for years. They argued that remittances flow through illegal channels can have no effect on the economic growth.

Imports are also one of the important determinants that indirectly affect the economy. As imports-led growth theory stated that imports are the key drivers of the economy. Moreover, endogenous theory postulate that imports are vital because it brings new technology and other factors to the domestic businesses. Several past studies have investigated the relationship between imports and economic growth and noted a causal relationship (Liu, Burridgez \& Sinclair, 2002). Ramos (2001) revealed a feedback relationship between economic growth and imports. Importing raw materials for manufacturing goods or advance technology increase the growth rate of the economy (Hang \& Zou, 1995). Also, Yanikkaya (2003) noted a positive relationship between imports and economic growth. Awokuse (2007) asserted that exports of goods and services raise the foreign exchange which facilitates imports and raises capital formation. On the contrary, Esfahani (1991) researched developed and developing countries and found no significant impact of imports in the developed countries, however, strong and developed the exports sector drive economic growth of developing countries. Similarly, some studies have found a robust relationship between trade, human development, and economic growth (Jawaid \& Waheed, 2018; 2017; Jawaid \& Raza, 2014; 2013 Jawaid, 2014).

\section{An Endogenous Growth Model for South Asian Countries}

In this paper, we aim to examine the impact of external resources on the economic growth of four South Asian Countries. For this purpose, we used three important external factors that contribute to the economic growth specifically of the developing nations. Following are the econometric model used in this study;

$$
G D P=\alpha_{0}+\alpha_{1} R E M_{i t}+\alpha_{2} F D I_{i t}+\alpha_{3} I M P_{i t}+\epsilon_{i t}
$$


Where GDP is the gross domestic product, used to measure the economic growth, REM is the worker's remittances, FDI refers to the foreign direct investment and IMP is the imports. The subscript of $i$ is the number of cross sections, and $t$ denotes the time in a year.

In this study, we used the balanced panel of four South Asian countries namely India, Pakistan, Srilanka, and Bangladesh covering annual data from 1983 to 2014. The data sets of all the studied variables are taken from the World Bank (World development Indicator, WDI).

For empirical analysis, we use the dynamic panel data techniques, more specifically pooled mean group (PMG) estimation to estimate the relationship of external resources and economic growth in South Asia. Though there are several other panel data analysis techniques such as fixed effect, random effect, pooled OLS and GMM estimation, but all have some limitations. For example, Pooled OLS is considered as a restrictive model due to its homogeneity in intercepts, slope, and cross-sections. Fixed effect model eliminates the restriction of homogeneity by using a dummy variable, which enables the model to capture both the cross-section and time effects. However, it gives biased results due to the loss of a degree of freedom (Baltagi, 2008). Also, random effect model reduces the problem of degree of freedom but assumes strict homogeneity in the model. According to Samargandi, Fidrmuc, and Ghosh (2015), generalized method of moment (GMM) distorts the estimation when the $\mathrm{N}$ is small, and $\mathrm{T}$ is large. Therefore, following the methodology of Arif, Kazmi, and Khan (2017), Jouini (2014), Asteriou (2009) \& Chen and Chen (2007), we use pooled mean group estimation to estimate the relationship in four South Asian countries from 1983 to 2014.

\section{Results and Discussion of Full Sample}

\section{Descriptive Statistics}

Table 1 shows the summary statistics of external resources and economic growth of South Asia. It shows that average gross domestic product of four South Asian countries is 9.84. Whereas the average foreign direct investment is 5.30; remittances are 8.20 and imports are 18.92.

Table 1: Descriptive statistics of variables (1983-2014)

\begin{tabular}{|l|c|c|c|c|}
\hline & GDP & FDI & REM & IMP \\
\hline Mean & 9.846 & 5.309 & 8.208 & 18.927 \\
\hline Std. Dev. & 8.131 & 7.946 & 7.635 & 5.579 \\
\hline Maximum & 25.097 & 20.678 & 22.674 & 31.236 \\
\hline Minimum & 1.014 & -0.030 & 0.730 & 6.860 \\
\hline
\end{tabular}

Source: Author's Construction 


\section{CD and CIPS Test}

To test the existence of cross-sectional independence in the data series, we used Pesaran (2004) CD test. It is also a prerequisite for the second-generation unit root test that the series are cross-section dependent. Table 1 Panel A illustrates the results of $\mathrm{CD}$ test; it confirms that the data series of all the variables are cross-sectionally dependent at $1 \%$ significance level. Pesaran (2007) CIPS test is used to assess the order of the data series. Table 1 Panel B suggests that all the variables are not in the same order of integration. GDP and FDI are stationary at the level, whereas, remittances and imports are stationary at first difference at the $1 \%$ significant level, indicating that each variable has a different level of integration. Therefore, for robustness, we further apply both the Pedroni (1999) and Westerlund (2007) panel cointegration test to check the long run association between the variables.

Table 2: Test for cross-sectional dependency and panel unit root test

\begin{tabular}{|l|c|c|c|c|}
\hline Panel A: & GDP & FDI & REM & IMP \\
\hline Variables & \multicolumn{5}{|l|}{} \\
\hline Pesaran CD Test & 2.209 & 9.219 & 6.005 & 4.929 \\
\hline P-Value & 0.027 & 0.000 & 0.000 & 0.000 \\
\hline Panel B: & & & & \\
\hline CIPS (Level) & -2.484 & -2.557 & -0.837 & -0.938 \\
\hline CIPS (1St Difference) & -5.771 & -5.189 & $-4.432^{* * * *}$ & $-6.151^{* * *}$ \\
\hline
\end{tabular}

$* * *$ denote the rejection of null hypothesis at $1 \%$ significance level

\section{Panel Cointegration Test}

Pedroni (1999), and Westerlund (2007) approaches assumed heterogeneity in the panels. Pedroni (1999) approach is residual based, whereas, Westerlund (2007) approach assumes cross-section dependence. The null hypothesis of Pedroni $(1999,2004)$ is no cointegration against alternate of cointegration. Table 3 shows that out of seven statistics, four rejects the null hypothesis of no cointegration confirming the long-run relationship between external resources and economic growth. 
Table 3: Pedroni panel cointegration test results

\begin{tabular}{|c|c|c|c|c|}
\hline \multicolumn{5}{|c|}{ Alternative hypothesis: common AR coefs. (within-dimension) } \\
\hline & \multicolumn{4}{|c|}{ Weighted } \\
\hline & Statistic & Prob. & Statistic & Prob. \\
\hline Panel v-Statistic & 0.504 & 0.306 & -0.011 & 0.504 \\
\hline Panel rho-Statistic & -1.902 & 0.028 & -1.465 & 0.071 \\
\hline Panel PP-Statistic & -4.190 & 0.000 & -2.874 & 0.002 \\
\hline Panel ADF-Statistic & -4.348 & 0.000 & -2.958 & 0.001 \\
\hline \multicolumn{5}{|c|}{ Alternative hypothesis: individual AR coefs. (between-dimension) } \\
\hline & Statistic & Prob. & & \\
\hline Group rho-Statistic & -1.165 & 0.121 & & \\
\hline Group PP-Statistic & -3.975 & 0.000 & & \\
\hline Group ADF-Statistic & -3.798 & 0.000 & & \\
\hline
\end{tabular}

Note: The null hypothesis of Pedroni panel cointegration is no cointegration.

Westerlund (2007) test results in Table 4 also confirmed for the long-run association between variables.

Table 4: Westerlund panel cointegration test

\begin{tabular}{|l|c|c|c|}
\hline \multicolumn{1}{|c|}{ Test } & value & $\mathrm{p}$-value & $\mathrm{p}^{\mathrm{a}}$ \\
\hline Group $-\tau$ & $\tau$-value \\
\hline Group $-\alpha$ & -2.651 & 0.033 & $0.030^{\text {** }}$ \\
\hline Panel - $\mathrm{T}$ & -6.704 & 0.639 & 0.270 \\
\hline Panel $-\alpha$ & -4.244 & 0.110 & 0.150 \\
\hline
\end{tabular}

** indicates the level of significance at $5 \%$

\section{Pooled Mean Group Estimates}

After confirming the integration property and long-run relationship between studied variables, we estimated equation (1) using Pesaran, Shin and Smith (1999) dynamic panel approaches; pooled mean group (PMG), and mean group (MG). As this study is only focusing on the top four South Asian countries, we assume that they have same economic, political and geographical conditions in the long-run, however, can have different conditions in the short-run due to the country-specific policies and regulations. Under long-run homogeneity assumptions, PMG estimators are more efficient as compared to MG estimators. These techniques are also appropriate when the variables have a different order of integration. In the present study, we have a different order of integration of the variables. Therefore, we apply both the mean group and pooled mean group estimators. To choose an appropriate estimator, we perform Hausman test. The null hypothesis of Hausman test is the insignificant difference 
between PMG and MG estimator and PMG is efficient. Table 5 shows the result of Hausman test, accepting the null hypothesis of PMG estimator efficiency. Therefore, we conclude that PMG is an appropriate estimator to estimate the model. The longrun estimations of PMG and MG both are illustrated in table 5. It shows that worker's remittances play a key role in stimulating the economic growth of South Asia. Moreover, imports play a positive but insignificant role in boosting the economy. However, the relationship of foreign direct investment and economic is found negative but insignificant. From the above findings, it is concluded that flow of remittances in the country particularly in Pakistan, India, Bangladesh and Sri Lanka significantly improve the economic growth. Hence, remittances are the main external resource that inevitably spurs the economy of selected South Asian countries.

Table 5: Pooled Mean Group and Mean Group estimation

\begin{tabular}{|l|c|c|c|c|c|c|}
\hline \multirow{2}{*}{ GDP } & \multicolumn{3}{|c|}{ Pooled Mean Group } & \multicolumn{3}{c|}{ Mean Group } \\
\cline { 2 - 7 } & Coef. & t-stats & Prob. & Coef. & t-stats & Prob. \\
\hline Rem & 0.157 & 1.880 & 0.061 & 0.394 & 1.320 & 0.188 \\
\hline Imp & 0.072 & 1.400 & 0.161 & -0.134 & -0.910 & 0.364 \\
\hline FDI & -0.024 & -0.080 & 0.935 & 0.249 & 1.240 & 0.216 \\
\hline \multicolumn{7}{|c|}{ Hausman Test Statistics: $h=0.78, p$-value $=0.855$} \\
\hline ECT & -0.701 & -2.98 & 0.003 & -0.785 & -5.13 & 0.000 \\
\hline
\end{tabular}

Source: Author's Construction

\section{Heterogeneous Panel Causality Test}

To test the bivariate causality between external resources and economic growth in South Asian countries, we apply Pairwise Dumitrescu Hurlin Panel Causality tests proposed by Dumitrescu and Hurlin (2012). This test is different from the Granger causality because it requires cross-sectional dependency in the panel. The null hypothesis assumes homogenous non-causality against the alternate hypothesis of heterogeneous non-causality between variables. Table 6 illustrates the results showing bidirectional causality between all the variables at the $10 \%, 5 \%$, and $1 \%$ significance level.

Table 6: Panel Heterogeneous non-causality test

\begin{tabular}{|l|c|c|c|}
\hline Null Hypothesis: & Zbar-Stat. & Prob. & Relation \\
\hline FDI does not homogeneously cause GDP & $3.381^{* * *}$ & 0.001 & \multirow{2}{*}{ Bidirectional } \\
\cline { 1 - 3 } GDP does not homogeneously cause FDI & $7.128 * * *$ & 0.000 & \\
\hline REM does not homogeneously cause GDP & $3.784 * * *$ & 0.000 & \multirow{2}{*}{ Bidirectional } \\
\cline { 1 - 3 } GDP does not homogeneously cause REM & $2.732^{* * *}$ & 0.006 & \multirow{2}{*}{ Bidirectional } \\
\cline { 1 - 3 } IMP does not homogeneously cause GDP & $1.821 * *$ & 0.069 & \\
\hline
\end{tabular}

$*, * * \& * * *$ denote a rejection of null hypothesis at $10 \%, 5 \% \& 1 \%$ significance level, respectively. 
However, in case of the causal relationship between foreign direct investment and imports with GDP, we noted that PMG coefficient is insignificantly related with GDP which might be due to the data generating process (DGP) assume in the analysis. One can note that the tested model is a multivariate, while causality test is a bivariate analysis which suffers variable biases due to DGP. For further robustness, we test bivariate PMG for imports and GDP. The statistics confirm the significant relationship between FDI and imports with GDP.

In the second part of the study, we examine the country-specific long-run and short-run elasticities and causality using ARDL bound testing approach and Granger causality test.

We apply Pesaran, and Shin (1999) ARDL bound testing approach by selecting Akaike Information Criteria (AIC) in order to use appropriate lag length. Table 7 presents the statistics of the bound testing approach of all the countries. The F-statistics of all the regions confirm the existence of cointegration among variables at $1 \%$, $5 \%$, and $10 \%$ significance level. In addition, Table 7 also represents the short-run and long-run estimations. The results confirm the positive linkage of remittances with economic growth in Pakistan and Srilanka in the long run, whereas, this relationship found unimportant in India and Bangladesh. Moreover, imports have an inverse relationship with the gross domestic product in Pakistan and Sri Lanka; however, on the other hand, imports play a significant role in boosting the economy of Bangladesh. In addition, the role of foreign investments found unimportant in all the economies in both the long run and short run.

Table 7: Comparison between regional and country- wise estimations

\begin{tabular}{|c|c|c|c|c|c|}
\hline \multicolumn{6}{|l|}{ Panel-A: ARDL Bound Test } \\
\hline Regressors & Pakistan & India & Bangladesh & Srilanka & Regional \\
\hline Lag Length & $1,1,2,2$ & $4,3,3,3$ & $1,0,0,0$ & $5,0,3,3$ & - \\
\hline F-Statistics calculated & 14.276 & 4.253 & 4.112 & 4.631 & - \\
\hline Upper Bound Critical Value & $5.61 * * *$ & $3.77 *$ & $3.77 *$ & $4.35 * *$ & \\
\hline \multicolumn{6}{|l|}{ Panel-B: Short-run Estimates } \\
\hline $\mathrm{D}(\mathrm{FDI})$ & 0.913 & -1.054 & 0.489 & -0.015 & 0.369 \\
\hline $\mathrm{D}(\mathrm{REM})$ & $-0.719 * *$ & $-4.463 * * *$ & -0.106 & $0.595 * * *$ & -0.633 \\
\hline $\mathrm{D}(\mathrm{IMP})$ & -0.229 & -0.242 & $0.187 * *$ & $0.189 * *$ & $0.127 * *$ \\
\hline CointEq(-1) (ECT) & $-1.137 * * *$ & $-1.803 * *$ & $-1.029 * * *$ & $-0.759 * * *$ & - \\
\hline \multicolumn{6}{|l|}{ Panel C: Long-run Estimates } \\
\hline FDI & 0.095 & -2.053 & 0.475 & -0.019 & -0.024 \\
\hline REM & $0.629 * * *$ & 0.431 & -0.103 & $1.015^{* * *}$ & $0.157^{* *}$ \\
\hline IMP & $-0.399 * * *$ & 0.298 & $0.182 * *$ & $-0.300 * *$ & 0.072 \\
\hline
\end{tabular}

Note: $* * *, * * *$ indicate $10 \%, 5 \%$ \& $1 \%$ significance level 
Figure 2: CUSUM and CUSUMQ test results

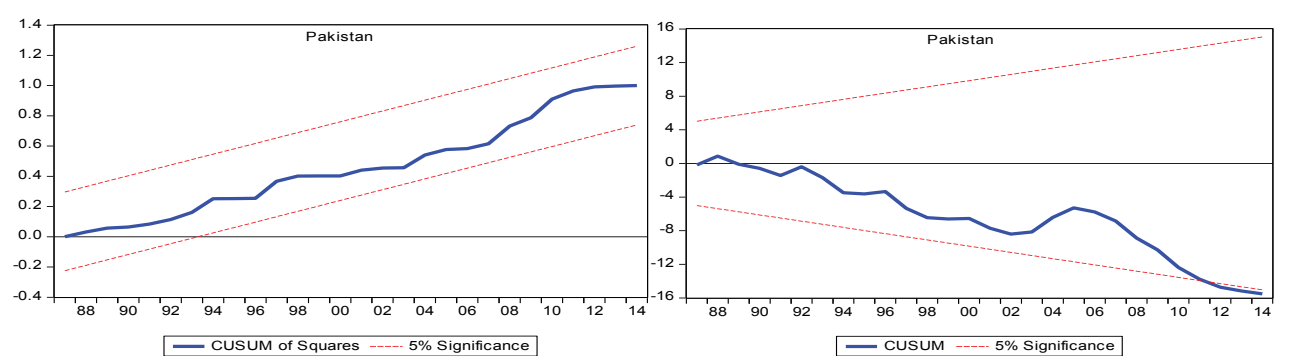

(1) Pakistan

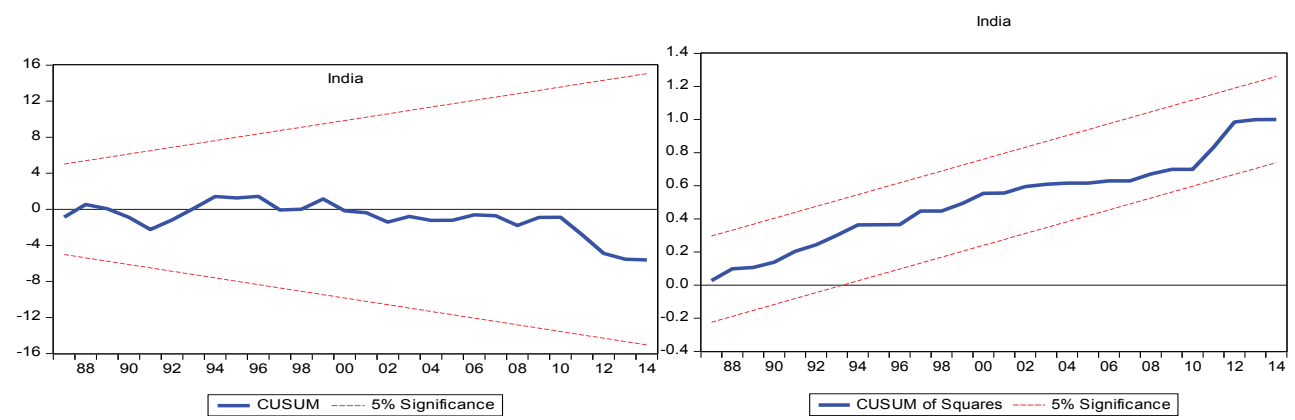

(2) India

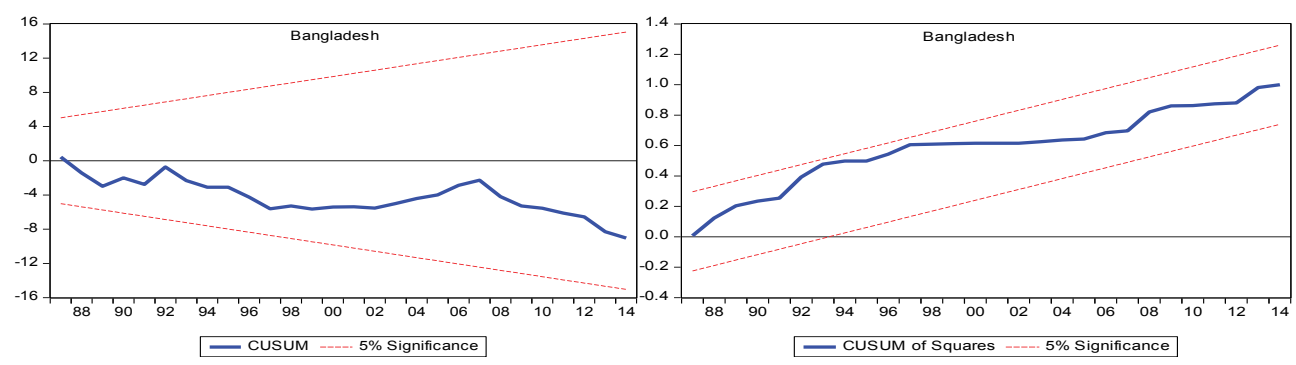

(3) Bangladesh

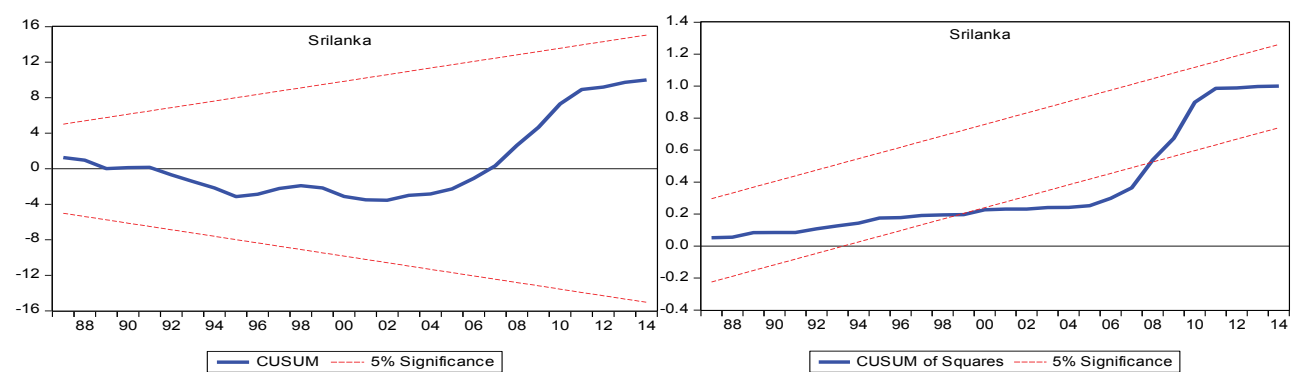


Due to the structural and political changes in the selected region of South Asia, we apply a stability test to check whether the coefficients are stable or not, using CUSUM and CUSUMQ given by Brown et al. (1975). Figure 2 gives the graph of CUSUM and CUSUMQ test results of all the countries. They indicate that the coefficients of only three regions fall in the straight lines of critical bounds at $5 \%$ significance level. However, in the case of Sri Lanka, the coefficients from the period 1998 to 2008 crossed the line of critical bound. Therefore, we conclude that the coefficients of Pakistan, India, and Bangladesh are consistent throughout the period starting from 1984 to 2014. Whereas the coefficients of Srilanka found unstable for few years, i.e., from 1998 to 2008, but it started stabilizing from 2009 till 2014.

The evidence of cointegration between external resources and gross domestic product in Pakistan, India, Bangladesh, and Sri Lanka suggest causality between variables at least in one direction. Table 8 presents the statistics of Granger causality of all regions. The results reveal that FDI, remittances, and GDP both have a bidirectional causal relationship in Pakistan. Whereas, there is unidirectional causality found among imports and GDP. Furthermore, there exists a two-way causality between imports, FDI and GDP and one-way Causality between remittances and GDP in India. In Bangladesh, remittances and GDP have a bi-directional causality. However, FDI and imports both have a unidirectional causal relation. One-way directional causality exists among all the variables in Sri Lanka.

Table 8: Granger causality test for South Asian countries

\begin{tabular}{|l|c|c|c|c|c|c|c|c|}
\hline & \multicolumn{2}{|c|}{ Pakistan } & \multicolumn{2}{c|}{ India } & \multicolumn{2}{c|}{ Bangladesh } & \multicolumn{2}{c|}{ Srilanka } \\
\hline Null Hypothesis & F-Stats & Prob. & F-Stats & Prob. & F-Stats & Prob. & F-Stats & Prob. \\
\hline FDI does not Granger Cause GDP & 3.655 & 0.066 & 4.176 & 0.050 & 7.212 & 0.012 & 0.188 & 0.668 \\
\hline GDP does not Granger Cause FDI & 8.005 & 0.009 & 6.136 & 0.019 & 1.568 & 0.221 & 11.628 & 0.002 \\
\hline REM does not Granger Cause GDP & 3.397 & 0.076 & 4.855 & 0.035 & 7.051 & 0.013 & 1.231 & 0.277 \\
\hline GDP does not Granger Cause REM & 2.919 & 0.099 & 1.989 & 0.169 & 6.339 & 0.018 & 1.886 & 0.181 \\
\hline IMP does not Granger Cause GDP & 0.259 & 0.615 & 3.825 & 0.060 & 5.242 & 0.030 & 0.864 & 0.361 \\
\hline GDP does not Granger Cause IMP & 16.087 & 0.000 & 8.831 & 0.006 & 2.269 & 0.143 & 4.211 & 0.050 \\
\hline
\end{tabular}

\section{Conclusion and Policy Implications}

In this globalized world, it is important to determine the external factors that contribute to the economic growth, particularly in the developing nations. As per the growth literature, foreign direct investment, remittances, and imports are the three most important external factors that play a crucial role in the developing economies. Previous researches have focused on the individual effect of the aforementioned ex- 
ternal factors on the economic growth. Therefore, this study aimed to investigate the combined as well as individual effects of foreign direct investment, remittances, and imports on the economic growth of leading South Asian economies. For this purpose, we used the balanced panel of four South Asian countries comprising India, Pakistan, Srilanka and Bangladesh spanning the time period of 1983-2014.

In this paper, we have used the advanced econometric techniques to estimate the model. Before estimating a model, we first checked the heterogeneity among variables by using Pesaran (2004) CD test. The existence of cross-sectional dependence motivated us to check the integration property of the data sets using second-generation Pesaran (2007) CIPS test. As the data series were integrated into different orders, therefore, we applied two robust heterogeneous panel cointegration techniques, i.e., Pedroni $(1999,2004)$ and Westerlund (2007) to examine the long run relationship between foreign direct investment, remittances, imports and gross domestic product. The statistics confirmed the robustness of cointegration because both the test rejects the null hypothesis of no cointegration. Hence, we concluded that all the focused variables have a long run relationship with the GDP.

We used pooled mean group (PMG) estimation for testing the hypotheses. The empirical results indicated that worker remittances are an important external determinant for the south Asian countries. However, foreign direct investment and imports were statistically insignificant. In the final step, we explored the causal relationship of the considered variables using Dumitrescu and Hurlin (2012) heterogeneous panel non-causality test. The results indicated the bidirectional causal relationship among all the variables.

This research finds that remittances are an important external resource for the economic growth of South Asian countries. These findings are useful for the head of the states and policymakers of the selected countries to get benefit from the flow of remittances. It is suggested that state should make a proper channel for remittances by using the strong financial system. Developing countries are facing major challenges associated with foreign capital flows such as transaction cost. The transaction cost of remittances is very high in most of the developing nations which hinder the flow of remittances into the country. In order to remove this bottleneck, the state should reduce transaction cost and allow free flow of remittances into the country. As per the finding, remittance inflow leads to economic growth. Therefore it is further suggested that user-friendly financial system should be developed in order to give ease to the recipient and subsequently it will help the government to measure the actual amount of remittances flow into the country. In addition, policymakers ought to formulate such policies that encourage transparency and remove hindrances and attract users to transfer money through a proper financial system.

Future studies can extend this analysis by adding more South Asian countries in the panel. It is also suggested that this model can be tested on other groups of countries, such as BRICs, G-20 and other Asian developing countries. In the current study, 
we examined the three important external factors that play a crucial role in the developing economies. However, there are some other external factors such as foreign aid, external debt that can also be added to the existing model.

\section{REFERENCES}

Almfraji, M., \& Almsafir, K, M. (2014). Foreign Direct Investment and Economic Growth Literature Review from 1994 to 2012. Procedia-Social and Behavioral Sciences, 129; 206-213.

Arif, I., Kazmi, S. W., \& Khan, L. (2017). Relationship between Trade Openness and Energy

Consumption in Oil Importing Asian Countries. Journal of Finance \& Economics Research, 2(1), 37-53.

Arif, I., Khan, L., Raza, S. A., and Maqbool, F., (2017) "External resources and economic growth: New evidence from EAGLE countries using PMG framework", Journal of Transnational Management, 22(4), http://dx.doi.org/10.1080/15475778.2017.1389597

Asteriou, D. (2009). Foreign aid and economic growth: New evidence from a panel data approach for five South Asian countries. Journal of policy modeling, 31(1), 155-161.

Awokuse, T. O. (2007). Causality between exports, imports, and economic growth: Evidence from transition economies. Economics Letters, 94(3), 389-395.

Balamurali, N. \& Bogahawatte, C., (2011). Foreign Direct Investment and Economic Growth in Sri Lanka. Sri Lankan Journal of Agricultural Economics, 6(1), 37-50.

Barajas, A., Chami, R., Fullenkamp, C., Gapen, M., \& Montiel, P. J. (2009). Do workers' remittances promote economic growth? IMF Working Papers, 1-22.

Barro, R. J., \& Lee, J. W. (1993). International comparisons of educational attainment. Journal of monetary economics, 32(3), 363-394.

Bashir, T., Mansha, A., Zulfiqar, R., \& Riaz, R. (2014). Impact of FDI on economy growth: a comparison of South Asian States \& China. European Scientific Journal, 10(1).

Baltagi, B. (2008). Econometric analysis of panel data. John Wiley \& Sons.

Borensztein, E., De Gregorio, J., \& Lee, J. W. (1998). How does foreign direct investment affect economic growth? Journal of International Economics, 45(1), 115-135.

Catrinescu, N., Leon-Ledesma, M., Piracha, M., \& Quillin, B. (2009). Remittances, institutions, and economic growth. World Development, 37(1), 81-92.

Chen, S. S., \& Chen, H. C. (2007). Oil prices and real exchange rates. Energy Economics, 29(3), 390-404.

Das, A., \& Chowdhury, M. (2011). Remittances and GDP dynamics in 11 developing countries: evidence from panel cointegration and PMG techniques. Romanian Economic Journal, 14(42), 3-23

Denault, J. (2011). A Comparative Analysis of Development: Foreign Direct Investment and Remittances in Latin America. Bryant Economic Research Paper, 4(3), 22-35.

Driffield, N., \&Jones, C. (2013). Impact of FDI, ODA and Migrant Remittances on Economic Growth in Developing Countries: A System Approach. European Journal of Development Research, 25(2), 173-196.

Dumitrescu, E. I., \& Hurlin, C. (2012). Testing for Granger non-causality in heterogeneous panels. Economic Modelling, 29(4), 1450-1460.

Demirgüç-Kunt, A., Córdova, E. L., Peria, M. S. M., \& Woodruff, C. (2011). Remittances and banking sector breadth and depth: Evidence from Mexico. Journal of Development Economics, 95(2), 229-241. 
Esfahani, H. S. (1991). Exports, imports, and economic growth in semi-industrialized countries. Journal of Development Economics, 35(1), 93-116

Giuliano, P., \& Ruiz-Arranz, M. (2009). Remittances, financial development, and growth. Journal of Development Economics, 90(1), 144-152.

Hermes, N., \&Lensink, R. (2003). Foreign direct investment, financial development and economic growth. The Journal of Development Studies, 40(1), 142-163.

Hussain, R., \& Anjum, G. A. (2014). Worker's Remittances and GDP Growth in Pakistan. International Journal of Economics and Financial Issues, 4(2), 376

Iamsiraroj, S., \& Ulubaşoğlu, M. A. (2015). Foreign direct investment and economic growth: A real relationship or wishful thinking? Economic Modelling, 51, 200-213.

Imai, K. S., Gaiha, R., Ali, A., \& Kaicker, N. (2014). Remittances, growth and poverty: New evidence from Asian countries. Journal of Policy Modeling, 36(3), 524-538.

Jawaid, S. T., \& Waheed, A. (2018). A macro econometric model for trade policy evaluation: evidence from Pakistan. Journal of Chinese Economic and Foreign Trade Studies, 11(1), 49-103.

Jawaid, S. T., \& Waheed, A. (2017). Contribution of international trade in human development of Pakistan. Global Business Review, 18(5), 1155-1177.

Jawaid, S. T., \& Saleem, S. M. (2017). Foreign capital inflows and economic growth of Pakistan. Journal of Transnational Management, 22(2), 121-149.

Jawaid, S. T., \& Raza, S. A. (2016). Effects of Workers' Remittances and its Volatility on Economic Growth in South Asia. International Migration, 54(2), 50-68.

Jawaid, S. T. (2014). Trade openness and economic growth: A lesson from Pakistan. Foreign Trade Review, 49(2), 193-212.

Jawaid, S. T., \& Raza, S. A. (2013). Effects of terms of trade on growth performance of India. Economic Modelling, 33, 940-946.

Jawaid, S. T., \& Raza, S. A. (2012). Workers' remittances and economic growth in China and Korea: an empirical analysis. Journal of Chinese Economic and Foreign Trade Studies, 5(3), 185-193.

Jouini, J. (2015). Linkage between international trade and economic growth in GCC countries: Empirical evidence from PMG estimation approach. The Journal of International Trade \& Economic Development, 24(3), 341-372.

Khathlan, A. K. (2012). The Link between Remittances and Economic Growth in Pakistan: A Boon to Economic Stability. British Journal of Economics, Management \& Trade 2 (3), 167-185.

Kumar, R. R., \& Stauvermann, P. J. (2014). Exploring the nexus between remittances and economic growth: a study of Bangladesh. International Review of Economics, 61(4), 399-415.

Niimi, Y., Ozden, C., \& Schiff, M. (2010). Remittances and the brain drain: skilled migrants do remit less. Annals of Economics and Statistics/Annales d'Économie et de Statistique, 123-141.

Li, X., \& Liu, X. (2005). Foreign direct investment and economic growth: an increasingly endogenous relationship. World Development, 33(3), 393-407.

Liu, X., Burridge, P., \& Sinclair, P. J. (2002). Relationships between economic growth, foreign direct investment and trade: Evidence from China. Applied Economics, 34(11), 1433-1440.

Lueth, E. (2006). A Gravity Model of Workers' Remittances. International Monetary Fund.

Manni, U. H., Siddiqui, S. A., \& Afzal, M. N. I. (2012). An empirical investigation on trade openness and economic growth in Bangladesh economy. Asian Social Science, 8(11), 154.

Nwaogu, G.U., \& J. Ryan, J.M. (2015). FDI, Foreign Aid, Remittances and Economic Growth in Developing Countries, Review of Development Economics 19(1), 100-115.

Pesaran, M. H. (2004). General diagnostic tests for cross section dependence in panels.

Pesaran, M. H. (2007). A simple panel unit root test in the presence of cross-section

dependence. Journal of Applied Econometrics, 22(2), 265-312.

Pedroni, P. (1999). Critical values for cointegration tests in heterogeneous panels with multiple regressors. Oxford Bulletin of Economics and statistics, 61(S1), 653-670. 
Pedroni, P. (2004). Panel cointegration: asymptotic and finite sample properties of pooled time series tests with an application to the PPP hypothesis. Econometric theory, 20(3), 597-625.

Ramos, F. F. R. (2001). Exports, imports, and economic growth in Portugal: evidence from causality and co-integration analysis. Economic Modelling, 18(4), 613-623.

Rao, B. B., \& Hassan, G. M. (2011). A panel data analysis of the growth effects of remittances. Economic Modelling, 28(1), 701-709.

Solow, R. M. (1956). A Contribution to the Theory of Economic Growth, Quarterly Journal of Economics, 70(1), 65-94

Samargandi, N., Fidrmuc, J., \& Ghosh, S. (2015). Is the relationship between financial development and economic growth monotonic? Evidence from a sample of middle-income countries. World Development, 68, 66-81.

Tang, C. F., \& Tan, B. W. (2014). The linkages among energy consumption, economic growth, relative price, foreign direct investment, and financial development in Malaysia. Quality \& Quantity, $1-17$.

Villaverde, J. \&Maza, A. (2014), Trade openness, income levels, and economic growth: the case of developing countries, 1970-2009. The Journal of International Trade \& Economic Development: An International and Comparative Review, 860-882

Westerlund, J. (2007). Testing for error correction in panel data. Oxford Bulletin of Economics and statistics, 69(6), 709-748.

Yanikkaya, H. (2003). Trade openness and economic growth: a cross-country empirical investigation. Journal of Development economics, 72(1), 57-89. 